Journal of Islamic Studies and Humanities

Vol. 1, No. 1 (2016) 67-92, doi: 10.21580/jish.11.1374

\title{
BATAS USIA IDEAL PERNIKAHAN PERSPEKTIF MAQASID SHARIAH
}

\author{
Holilur Rohman \\ Universitas Islam Negeri Sunan Ampel Surabaya \\ elrahman10@gmail.com
}

\begin{abstract}
An ideal marriage is a marriage that able to achieve the goal of becoming a family wedding sakinah, mawaddah wa rahmah. Al-Qur'an and Sunnah did not explain in detail about the limitations of marriageable age. There are three perspectives on the age limit to get married in Indonesia, first, the perspective of Islamic law, the second law No. 1 in 1974 allow a woman to get married at the age of 16 and men at age 19, the third, BKKBN which advocated age at marriage ideal namely the minimum age for women 21 years and for men 25 years old. But in different perspective, the ideal age of marriage maqasid shari'ah perspective for women 20 years and for men 25 years, because at this age considered to have been able to realize the goal wedding (maqasid shari'ah) such as: creating a family sakinah mawaddah wa rahmah, keeping the lineage, maintaining the pattern of family relationships, maintaining diversity and deemed ready in terms of economic, medical, psychological, social, religious.
\end{abstract}

Keywords: marriage, maqasid sharia, married ideal age limit

\begin{abstract}
Abstrak
Pernikahan yang ideal adalah pernikahan yang mampu mencapai tujuan pernikahan menjadi keluarga yang sakinah, mawaddah dan rahmah. AlQur'an dan as-Sunnah menjelaskan secara rinci tentang batasan usia menikah. Ada tiga perspektif mengenai batas usia menikah di Indonesia, pertama, perspektif hukum Islam, kedua, undang-undang no 11974 mengijinkan seorang perempuan menikah pada usia 16 tahun dan laki-laki pada usia 19 tahun, ketiga, BKKBN yang menganjurkan usia kawin yang ideal yaitu usia minimal bagi perempuan 21 tahun dan bagi laki-laki 25 tahun.. Akan tetapi usia ideal perkawinan perspektif maqasid shari'ah adalah bagi perempuan 20 tahun dan dan bagi laki-laki 25 tahun, karena pada usia ini dianggap telah mampu merealisasikan tujuan-tujuan pensyariatan pernikahan (maqasid shariah) seperti: menciptakan keluarga yang sakinah mawaddah wa rahmah, menjaga garis keturunan, menjaga pola hubungan keluarga, menjaga keberagamaan dan dipandang siap dalam hal aspek ekonomi, medis, psikologis, sosial, agama.
\end{abstract}

Kata kunci: Pernikahan, maqasid shari'ah, batas usia ideal menikah

ISSN 2527-8401 (p) 2527-838X (e)

(C) 2016 JISH Pascasarjana UIN Walisongo Semarang

http://journal.walisongo.ac.id/index.php/jish 


\section{Pendahuluan}

Pernikahan dalam Islam banyak diatur dalam teks al-Qur'an dan Hadis, baik secara prinsip-prinsip umum, ataupun secara detail tekhnis pelaksanaannya. Para fuqaha' maz̧hab yang mencoba mensistematiskan aturan-aturan pernikahan dan dituangkan dalam lembaran-lembaran kitab fiqh. Sifat fiqh yang merupakan pemahaman para ahli fiqh dengan mendialektikakan antara teks suci dan realitas yang dihadapi, maka menjadi wajar ketika terjadi banyak perbedaan pendapat antara para imam mazhab.

Terlepas dari perbedaan pendapat itu, secara umum ulama' sepakat bahwa tujuan pernikahan adalah membentu keluarga yang bahagia, sakinah mawaddah wa rahmah. Demi terealisasinya tujuan agung tersebut akhirnya fuqaha merumuskan persyaratan dan rukun pernikahan sesuai dengan mazhabnya masing-masing. Akan tetapi, dalam fiqh klasik belum ada kesepakatan dan kejelasan tentang batas umur ideal pernikahan. Kalaupun ada, sebatas memberikan persyaratan bahwa syarat kedua pasangan yang akan menikah adalah dewasa.

Namun yang perlu digaris bawahi disini adalah bahwa teks alQur'an dan al-Sunnah tidak pernah memberi batasan yang sangat tegas terkait umur minimal seseorang untuk bisa melangsungkan pernikahan. Ulama fiqh klasik juga tidak memberi batasan yang begitu tegas dan masih ada perbedaan pendapat tentang batas umur tersebut.

Dalam kitab Fiqh Marahib al-Arba'ah tidak ada penjelasan rinci mengenai batas umur seseorang boleh melangsungkan pernikahan. Ketika membahas persyaratan calon suami dan istri yang akan menikah, ulama' empat mazhab tidak memberi batasan secara konkrit tentang batas umur menurut hukum Islam.

Persoalan usia pernikahan juga menjadi pembahasan dari pasalpasal yang diatur dalam UU No. 1 Tahun 1974 tentang perkawinan. Dijelaskan pada pasal 7 Undang-Undang Nomor 1 Tahun 1974 tentang Perkawinan bahwa umur minimal boleh menikah adalah 16 bagi perempuan dan 19 tahun bagi laki-laki. 
Sebagaimana UU No. 1 Tahun 1974 tentang perkawinan di atas, BKKBN sebagai lembaga pemerintah yang bertanggung jawab untuk menekan laju penduduk Inonesia dan mengatur agar keluarga Indonesia menjadi keluarga sejahtera, mempunyai program yang berkaitan dengan usia perkawinan, yaitu program pendewasaan usia perkawinan (PUP).

Rencana strategis atau yang biasa disebut RENSTRA Pembangunan KKB tahun 2010-2014, menetapkan median usia kawin pertama adalah 21 tahun. Akan tetapi, berdasarkan hasil Sensus Penduduk tahun 2010, median usia kawin pertama di Indonesia adalah 18,6 tahun. Data SDKI 2007 menunjukkan usia kawin pertama adalah 19,8 tahun dan menurun menjadi 19 tahun pada SDKI 2012. ${ }^{1}$ Perbedaan data tersebut antara lain disebabkan oleh faktor sosial, ekonomi dan budaya, termasuk terbatasnya akses terhadap informasi tentang kesehatan reproduksi. Di berbagai wilayah Indonesia, orang tua merasa malu kalau anak perempuannya belum menikah pada usia 20 tahun. Mereka belum memahami bahwa untuk menikah dan memiliki anak, seorang perempuan sebaiknya sudah memiliki kesiapan fisik dan mental.

Berkaitan dengan hal tersebut, walaupun UU No. 1 Tahun 1974 tentang Perkawinan mengijinkan seorang perempuan menikah pada usia 16 tahun dan laki-laki pada usia 19 tahun, program KB mengembangkan program Pendewasaan Usia Perkawinan (PUP) yang menganjurkan usia kawin yang ideal untuk menikah dan memiliki anak pertama, yaitu di atas 20 tahun. Bagi Indonesia yang menempati urutan ke 5 penduduk terpadat di dunia, tentu saja penundaan usia perkawinan menjadi masalah mendesak yang perlu mendapatkan perhatian besar dari pemerintah untuk menghindari angka kelahiran yang tidak terkendali.

Menurut hukum Islam, walaupun tidak ada penjelasan yang pasti mengenai batas usia menikah bagi laki-laki dan perempuan, akan tetapi ada teori hukum Islam yang mampu merumuskan batas usia tersebut berdasarkan pemahaman yang universal, integral, dan

1 ww.bkkbn.go.id/arsip/.../RENSTRA\%20BKKBN\%2020102014.pdf (diakses 12 Januari 2014) 
komprehensif, yaitu teori Maqasid shariah, sebuah teori hukum Islam yang tidak hanya melihat tekstualitas al-Qur'an dan sunnah saja dalam merumuskan sebuah hukum, akan tetapi juga melihat faktor lain berupa maksud dan tujuan pemberlakuan hukum.

Maqasid al-shariah dapat dimaknai dengan makna-makna (pemahaman) yang dikehendaki oleh shar' (Allah dan Rasul-Nya) untuk bisa terealisasikan lewat tashri' dan penetapan hukumhukumnya yang di-istinbat (ambil) oleh para mujtahid lewat teks-teks shari'at." 2 Merujuk kepada definisi tersebut. maka sasaran utama dari maqasid adalah menciptakan kemaslahatan kepada umat manusia secara umum, sebab yang menjadi target shari'ah adalah manusia itu sendiri.

Secara singkat, walaupun tidak ada teks al-Qur'an dan sunnah mengenai batas usia menikah, akan tetapi teori Maqasid shariah mampu menjangkau maksud dan tujuan hukum Islam sehingga bisa merumuskan batas usia ideal melangsungkan pernikahan. Batasan usia ideal perspektif maqasid shari'ab ini tentunya mempertimbangkan banyak aspek, seperti kajian terhadap teks al-Qur'an dan Sunnah mengenai tujuan pernikahan, serta pandangan ilmu kontemporer seperti medis, psikologi, antropologi, sosiaologi, dan lainnya agar pemahaman yang dihasilkan bersifat komprehensif dan integral.

Ada beberapa penelitian dan tulisan yang membahas tentang maqasid shari'ah, baik berupa buku khusus yang fokus membahas secara mendetail tentang maqasid shari'ah, atau buku ushul fiqh yang di dalamnya juga ada pembahasan maqasid shariah, atau berupa penelitian dan tulisan lepas yang mengkaji pemikiran maqasid shariah menurut tokoh tertentu.

Rumusan masalah yang akan dibahas dalam artikel ini adalah: (1). Bagaimana batasan minimal umur pernikahan dalam teks al-Qur'an dan Hadis? (2). Bagaimana batasan minimal umur pernikahan dalam UU No, 1 tahun 1974 tentang pernikahan?. (3). Bagaimana batasan minimal umur pernikahan dalam program Pendewasaan Usia

2 Jasser Auda, Maqasid al-Shari'ah as Philosophy of Islamic Law: A System Approach (London \& Washington: The International Institute of Islamic Thought, 2008), 2 
Perkawinan oleh BKKBN? (4). Bagaimana batas umur ideal pernikahan menurut maqasid shari'ab?

\section{Metode Penelitian}

Jenis penelitian ini adalah penelitian pustaka, yaitu tentang batas ideal pernikahan perspektif maqasid sha'riah, juga kualitatif yang bersifat deskriptif-analitis, yaitu berusaha mendiskripsikan secara detail tentang batas usia ideal pernikahan dari berbagai perspektif, yaitu dari al-Qur'an dan hadis, UU No.1 tahun 1974 tentang perkawinan, dan juga menurut BKKBN, kemudian isi dari data yang diperoleh tersebut dianalisa dan diinterpretasi untuk dengan menggunakan teori maqasid shariah untuk menentukan batas usia minimal pernikahan yang boleh dilangsungkan oleh uamt Islam.

Sesuai dengan fokus dan rumusan masalah dalam penelitian ini, maka data-data yang akan dikumpulkan meliputi:

a. Konsep batas usia pernikahan dalam al-Qur'an dan hadis

b. Batas usia pernikahan dalam UU No. 1 tahun 1974

c. Batas usia pernikahan menurut program Pendewasaan Usia Perkawinan oleh BKKBN

Sumber primer penelitian ini adalah buku-buku tentang batas usia pernikahan sesuai kebutuhan peneliti, yaitu: 1) Kitab al- Fiqh Ala Madzabib al-Arba'ah, Jilid 4 karya Abdurrohman al-Jaziri, 2) Amir Syarifuddin, Hukum Perkawinan Islam di Indonesia, 3) buku Undangundang no.1 tahun 1974 tentang perkawinan, dan rujukan tentang program pendewasaan usia perkawinan.

Sedangkan refrensi yang skunder adalah buku dan kitab yang berkaitan dengan maqasid shari'ah dan ushul fiqh (metodologi hukum Islam), baik secara langsung maupun tidak langsung, karena penelitian ini banyak membahas tentang metodologi hukum Islam.

Pengumpulan data di lapangan akan diawali dengan identifikasi subjek penelitian dengan mempertimbangkan kebutuhan data penelitian, kemudian dilakukan penggalian dan penelusuran data melalui studi pustaka dengan mendalami dan menganalisa refrensi primer dan skunder yang berkaitan dengan judul penelitian. Apabila data yang diperoleh belum mencukupi kebutuhan data penelitian, 
maka akan dilakukan studi pustaka lanjutan agar data yang dibutuhkan bisa terkumpul.

Dalam analisis data akan digunakan prosedur analisa model Miles \& Huberman, yaitu menggunakan analisis interaktif. Data yang diperoleh dari pustaka direduksi sehingga menemukan tema-tema dan pola pokok yang relevan dengan penelitian, kemudian disajikan dalam bentuk narasi sesuai dengan katagorisasi data yang selaras dengan permasalahan penelitian. Reduksi data dan penyajian data adalah dua komponen analisis yang dapat dilakukan secara bersamasama pada saat pengumpulan data lapangan. Setelah reduksi data telah tersajikan atau dibuat display data, maka langkah berikutnya penarikan kesimpulan atau ferivikasi yang mampu menjawab permasalahn penelitian. ${ }^{3}$

Penetapan keabsahan data yang ditentukan melalui empat kreteria yaitu: derajat keterpercayaan (credibility), keteralihan (transferability), kebergantungan (dependability), dan kepastian (confirmability), dalam penelitian ini akan digunakan teknik pemeriksaan keabsahan data sebagai berikut:

a. Credibility

Dalam pengecekan derajat keterpercayaan (credibility) data, peneliti akan menggunakan teknik Triangulasi ${ }^{4}$ dengan melakukan pembandingan dan pengecekan derajat keterpercayaan suatu informasi yang diperoleh melalui sumber atau metode yang lain.

b. Transferability

Dalam pengecekan derajat keteralihan, peneliti akan menggunakan teknik uraian rinci (thick description) ${ }^{5}$. Data akan

${ }^{3}$ Matthe B. Miles, A. Michael Huberman, Qualitative Data Analysis, Tjetjep Rohendi Rohidi (Penerjemah) Analisa Data Kualitatif, Buku Sumber Tentang MetodeMetode Baru, (Jakarta, UI=Press: 1992), 16-20

4 Triangulasi merupakan teknik pemeriksaan keabsahan data dengan memanfaatkan sesuatu yang lain, bisa berupa sumber lain, metode lain, penyidik lain dan atau teori lain. (lihat Lexy J. Moleong, Metode Penelitian Kualitatif), 230

5 Teknik ini menuntut peneliti untuk melaporkan hasil penelitian dengan uraian yang seteliti dan secermat mungkin yang menggambarkan konteks tempat penelitian diselenggarakan. lihat Lexy J. Moleong, Metode Penelitian Kualitatif, 337-338) 
diuraikan sesuai dengan konteksnya sehingga dapat dipahami makna yang terkandung dalam data.

c. Confirmability

Dalam pengecekan derajat kepastian (confirmability), akan digunakan pula teknik penelusuran audit kepastian. Dalam hal ini audit akan difokuskan pada keputusan auditi (peneliti) dalam penelusuran data dan penggunaan metodologinya. ${ }^{6}$

\section{Seputar Batas Umur Pernikahan}

Mengenai batas umur pernikahan, penelitian ini mencoba mendiskripsikan tiga perspektif yang masing-masing mempunyai paradigmanya sendiri. Ketiga perspektif inilah yang nantinya akan menjadi objek pembahasan jika dielaborasi dengan teori maqasid shariah. Tiga persepektif tersebut adalah:

1. Perspektif hukum Islam (al-Qur'an dan Sunnah, serta pendapat ulama' fiqh)

Pada dasarnya dalam al-Quran dan al-Sunnab tidak ada keterangan yang jelas tentang batasan umur menikah. Kedua sumber tersebut hanya menegaskan bahwa seseorang yang akan melangsungkan pernikahan haruslah merupakan orang yang sudah layak dan dewasa sehingga bisa mengatur dan menjalani kehidupan rumah tangganya dengan baik. Dan dengan kedewasaan itu pulalah pasangan suami istri akan mampu menunaikan hak dan kewajibannya secara timbal balik. Dalam surat al-Nisa' ayat 6 disebutkan:

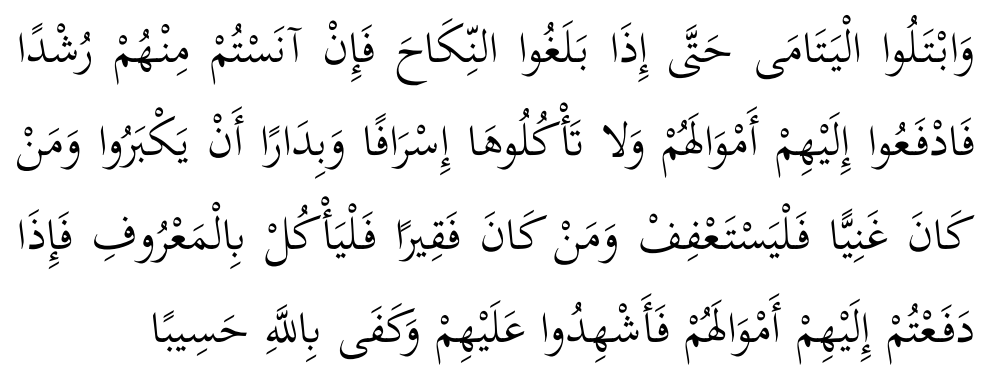

Dan ujilah anak yatim itu sampai mereka cukup umur untuk kawin. Kemudian jika menurut pendapatmu mereka telah cerdas (pandai

${ }^{6}$ Ibid, 342-343

Vol. 1, No. 1 (2016) 
memelihara harta), maka serahkanlah kepada mereka hartahartanya. dan janganlah kamu makan harta anak yatim lebih dari batas kepatutan dan (janganlah kamu) tergesa-gesa (membelanjakannya) sebelum mereka dewasa. barang siapa (di antara pemelihara itu) mampu, Maka hendaklah ia menahan diri (dari memakan barta anak yatim itu) dan barangsiapa yang miskin, maka boleblab ia makan harta itu menurut yang patut. Kemudian apabila kamu menyerabkan harta kepada mereka, Maka hendaklah kamu adakan saksi-saksi (tentang penyerahan itu) bagi mereka. dan cukuplah Allah sebagai Pengawas (atas persaksian itu)."

Ayat diatas menegaskan bahwa seseorang bisa menikah ketika dia sudah cukup umur untuk menikah. Atau dengan bahasa lain, pernikahan seseorang boleh dilakukan ketika dia sudah balig atau dewasa.

Bahkan sejarah pun seakan tidak pernah usang untuk mengatakan bahwa Nabi Muhammad menikahi Siti Aisyah ketika umur Aisyah masih belia. Hadis nabi dari Aisyah yang diriwayatkan oleh al-Bukhari, Muslim, Abu Daud dan al-Nasa'i yang artinya: "Nabi mengawiniku pada saat usiaku 6 tahun dan hidup bersama saya pada usia 9 tahun." Sedangkan pada zaman sahabat Nabi Muhammad saw, ada yang juga menikahkan putra-putrinya atau keponakannya yang masih berusia kecil. Sebagai contoh adalah Sahabat Ali bin Abi Thalib yang menikahkan anak perempuannya yang bernama Ummi Kuls|um dengan Sahabat Umar Bin Khattab ketika masih muda. Begitu juga sahabat Urwah Bin Zubair yang menikahkan anak perempuan saudaranya dengan anak laki-laki saudaranya yang lain sedangkan umur kedua keponakannya itu masih di bawah umur. ${ }^{8}$

Dalam kitab Fiqh Mazabib al-Arba'ah tidak ada penjelasan rinci mengenai batas umur seseorang boleh melangsungkan pernikahan. Ketika membahas persyaratan calon suami dan istri yang akan menikah, ulama' empat mazhab tidak memberi batasan secara konkrit tentang batas umur menurut hukum Islam. Rinciannya sebagaimana berikut:

${ }^{7}$ Departemen Agama RI, al-Qur'an dan Terjemahannya (Surabaya, Surya Cipta Aksara, 1993), 115-116.

${ }^{8}$ Husein Muhammad, Fiqh Perempuan (Yogyakarta: LKIS, 2007), 92. 
a. Menurut Hanafiyah. syarat kedua calon mempelai adalah berakal, balig dan merdeka (bukan budak).

b. Menurut Syafi'iyah. syarat calon suami adalah bukan mahram dari calon istri, tidak terpaksa, tertentu dan harus tahu kehalalan menikahi calon istri. Sedangkan syarat calon istri adalah bukan mahram calon suami, harus tertentu, tidak ada halangan pernikahan, dan lain-lain.

c. Menurut Hanabilah. syaratnya adalah harus tertentu. harus ada kerelaan dan tidak boleh dalam keadaan terpaksa.

d. Menurut Malikiah. syaratnya adalah tidak ada larangan yang menghalangi pernikahan, pihak perempuan bukanlah istri orang lain, istri tidak pada masa iddah, calon suami istri bukanlah satu mahram. ${ }^{9}$

Menurut Wahbah Zuhaili, syarat kedua calon mempelai yang akan menikah ada tiga:

a. Berakal

b. Baligh dan merdeka

c. Perempuan yang akan dinikahi harus ditentukan secara utuh. ${ }^{10}$

Selain syarat diatas, ada dua syarat yang harus dipenuhi untuk melangsungkan pernikahan, yaitu mukallaf (orang yang dibebankan untuk melaksankan hukum syar'i) dan istita'ah (mampu melaksankan hukum syar'i).

Secara global Amir Syarifuddin dalam bukunya Hukum Perkawinan Islam di Indonesia menyebutkan ada lima syarat yang harus dipenuhi oleh calon suami dan istri agar sab melaksanakan pernikahan, yaitu:

a. Laki-laki dan perempuan yang melangsungkan pernikahan haruslah sama-sama beragama Islam.

b. Keduanya harus jelas identitasnya dan bisa dibedakan dengan orang lain, baik terkait dengan nama, keberadaan, jenis kelamin dan hal-hal lainnya yang berkenaan dengan dirinya.

9 Abdurrahman al-Jaziriy, Kitab al- Fiqh Ala Madzabib al-Arba'ah, Jilid 4 (Beirut: Darul Fikr, t.t), 13-22.

${ }^{10}$ Wahbah Zuhailiy, al-Fiqh al-Islami wa Adillatubu, juz 9 (tk: tp, tt), 84. 
c. Kedua belah pihak telah setuju untuk menikah dan juga setuju dengan pihak yang mengawininya. Tentang izin dan persetujuan dari kedua belah pihak yang akan melangsungkan pernikahan ulama fiqh berbeda pendapat dalam menyikapinya.

d. Antara kedua belah pihak tidak ada hal-hal yang terlarang untuk melangsungkan pernikahan.

e. Kedua belah pihak telah mencapai usia yang pantas dan layak untuk melangsungkan pernikahan.

Pada pembahasan batas usia yang pantas dan layak untuk melangsungkan pernikahan inilah al-Quran maupun al-Sunnah tidak memberi penjelasan yang tegas tentang batasannya. Dengan mengutip pendapat Ibnu al-Humam dalam dalm kitab fiqh yang berjudul Syarb Fath al-Qadir, Amir Syarifuddin menyimpulkan bahwa pernikahan yang dilangsungkan antara laki-laki dan perempuan yang masih kecil hukumnya adalah sah. ${ }^{11}$

\section{Perspektif Undang-Undang No.1 Tahun 1974 tentang Perkawinan}

Undang-undang no 1 tahun 1974 tentang perkawinan adalah manifestasi dari hukum Islam yang dikodifikasi dan dilegalkan menjadi aturan negara. Pada pasal 7 Undang-Undang Nomor 1 tahun 1974 Tentang Perkawinan dijelaskan bahwa umur minimal boleh menikah adalah 16 bagi perempuan dan 19 tahun bagi laki-laki. Pasal 7 Undang-Undang Nomor 1 tahun 1974 tentang perkawinan berbunyi:

a. Perkawinan hanya diizinkan jika pihak pria sudah mencapai umur 19 (sembilan belas) tahun dan pihak wanita sudah mencapai umur 16 (enam belas) tahun.

b. Dalam hal penyimpangan terhadap ayat (1) pasal ini dapat meminta dispensasi kepada pengadilan atau pejabat yang ditunjuk oleh kedua orang tua pihak pria maupun wanita.

3. Perspektif BKKBN

${ }^{11}$ Amir Syarifuddin, Hukum Perkawinan Islam di Indonesia (Jakarta, Kencana, 2006), 66 . 
Walaupun UU No. 1 Tahun 1974 tentang Perkawinan mengijinkan seorang perempuan menikah pada usia 16 tahun dan laki-laki pada usia 19 tahun, program KB mengembangkan program Pendewasaan Usia Perkawinan (PUP) yang menganjurkan usia kawin yang ideal untuk menikah dan memiliki anak pertama, yaitu usia minimal 21 tahun bagi perempuan dan 25 tahun bagi laki. Batasan usia ini dianggap sudah siap baik dipandang dari sisi kesehatan maupun perkembangan emosional untuk menghadapi kehidupan berkeluarga. ${ }^{12}$. Bagi Indonesia yang menempati urutan ke 5 penduduk terpadat di dunia, tentu saja penundaan usia perkawinan menjadi masalah mendesak yang perlu mendapatkan perhatian besar dari pemerintah untuk menghindari angka kelahiran yang tidak terkendali.

Pendewasaan Usia Perkawinan (PUP) adalah upaya untuk meningkatkan usia pada perkawinan pertama, sehingga pada saat perkawinan mencapai PUP bukan sekedar menunda perkawinan sampai usia tertentu saja, akan tetapi juga mengusahakan agar kehamilan pertama terjadi pada usia yang cukup dewasa. Apabila seseorang gagal mendewasakan usia perkawinannya, maka diupayakan adanya penundaan kelahiran anak pertama. Penundaan usia kehamilan dan kehamilan anak pertama ini dalam istilah komunikasi, informasi, dan edukasi (KIE) disebut sebagai anjuran untk mengubah bulan madu menjadi tahun madu.

Pendewasaan usia perkawinan merupakan bagian dari program Keluarga Berencana Nasional. Program PUP akan memberikan dampak terhadap peningkatan umur kawin pertama yang pada gilirannya akan menurunkan Total Fertility Rate (TFR). Tujuan program Pendewasaan Usia Perkawinan (PUP) ini adalah untuk memberikan pengertian dan kesadaran kepada remaja agar dalam merancanakan keluarga, mereka dapat mempertimbangkan berbagai aspek berkaitan dengan kehidupan berkeluarga, kesiapan fisik, mental

${ }^{12} \mathrm{BKKBN}$; Direktorat Remaja dan Perlindungan Hak-Hak Reproduksi, Pendewasaan Usia Perkawinan dan Hak-hak Reproduksi bagi Remaja Indonesia Perempuan, (Jakarta: 2010), 19 
emosional, pendidikan, sosial, ekonomi, serta menentukan jumlah dan jarak kelahiran.

Tujuan PUP ini seperti berimplikasi pada perlunya peningkatan usia kawin yang lebih dewasa. Program PUP dalam program KB bertujuan meningkatkan usia kawin perempuan umur 21 tahun serta menurunkan kelahiran pertama pada usia ibu di bawah 21 tahun menjadi sekitar $14 \%{ }^{13}$

\section{Batas Usia Ideal Menikah Perspektif Maqashid Shari’ah}

Secara etimologi, maqasid adalah bentuk plural (jamak) dari kata maqsad yang berarti sesuatu yang dituju atau tujuan yang ingin dicapai. Kata al-Shari'ah berarti tempat mengalirnya air. ${ }^{14}$ Secara terminologis shari'ah adalah hukum-hukum Allah yang diperuntukkan kepada manusia yang berisi tentang kebijaksanaan dan kesejahteraan dalam kehidupan di dunia dan di akhirat. Dengan demikian, aturan apa pun yang menggantikan keadilan dengan ketidakadilan, belas kasih dengan lawan, kebaikan bersama dengan kejahatan, atau kebijaksanaan dengan omong kosong, adalah aturan yang tidak termasuk dalam Shari'ah, meskipun jika hal itu diklaim oleh para mufassir.

Sedangkan secara terminologi, kata Maqasid al-Shari'ah adalah tujuan, nilai, dan faidah yang ingin dicapai dari dituntunkannya shariah baik secara global maupun secara terperinci. ${ }^{15}$ Jasser Audah menjelaskan Maqasid al-Shariah secara aplikatif. Menurut Jasser, Maqasid al-Shari'ab adalah cabang ilmu keislaman yang menjawab segenap pertanyaan-pertanyaan yang sulit dan diwakili oleh sebuah kata yang tampak sangat sederhana, yaitu "mengapa?", seperti beberapa pertanyaan berikut? Mengapa seorang muslim sholat? mengapa zakat dan puasa merupakan salah satu rukun Islam?Mengapa berlaku baik terhadap tetangga merupakan kewajiban dalam Islam? Mengapa minum minuman beralkohol,

\section{Ibid, 20}

${ }^{14}$ Ahmad al-Raisuni, al-Fikru al-Maqasidi Qawa'idubu wa Fawa'idubu, (Dar alBaida': Ribat: 1999), hlm. 13

15 idem 
walaupun sedikit, adalah dosa besar dalam Islam? Mengapa hukuman mati ditetapkan bagi orang yang memperkosa atau membunuh secara sengaja? ${ }^{16}$

Jasser menambahkan bahwa Maqasid al-Shari'ab adalah sejumlah tujuan yang baik yang diusahakan oleh shari'at Islam dengan cara memperbolehkan atau melarang suatu hal. Maqasid al-Shari'ah juga berarti sejumlah tujuan ilahi dan konsep akhlak yang melandasi proses al-tash'ri' al-islami (penyusunan hukum berdasar shariat Islam), seperti prinsip keadilan, kehormatan manusia, kebebasan kehendak, kesucian, kemudahan, kesetiakawanan, dan lain sebagainya. ${ }^{17}$

Dalam kajian hukum Islam, biasanya para ulama fiqh klasik mengkategorikan maqasid al-shari'ah sebagai bagian dari ilmu usul alfigh. Namun kategerosasi ini ditolak oleh Jasser, dengan alasan bahwa maqasid mempunyai substansi yang berbeda dengan ushul fiqh. Menurutnya, ilmu usul al-figh sebagai ilmu banyak terfokus kepada lahiriyah teks, sementara maqasid lebih terfokus kepada makna yang ada di balik teks. Pendapat ini sekaligus menegaskan kesepahaman Jasser terhadap pendapat Shekh al-Tahir Ibn 'Asyur tentang kemandirian maqasid dari disiplin ilmu usul al-figh.

Khusus bab pernikahan, salah seorang pakar maqasid shariah, Jamaluddin Atiyyah, menjelaskan secara rinci tentang maqasid atau tujuan dari pensyariatan pernikahan (keluarga) dengan cara memahami dan menafsrikan teks al-Qur'an dan sunnah tentang maqasid shari'ah pernikahan, serta memadukan beberapa pendapat dari pakar maqasid lainnya. Menurut Jamaluddin Atiyyah, maqasid shari'ah dari pernikahan adalah:

1. Mengatur hubungan laki-laki dan perempuan

Pernikahan dalam Islam datang sebagai koreksi terhadap bentuk pernikahan di arab sebelm datangnya Islam yang dianggap tidak mencerminkan nilai-nilai kemanusiaan. Pernikahan sebelum Islam memposisikan manusia layaknya binatang, apalagi kedudukan seorang perempuan yang jauh di bawah kedudukan laki-laki.

${ }^{16}$ Jasser auda, Maqāsid al-Sharìah: A Beginner's Guide, terjemah oleh 'Ali Abdelmon'im, Al-Maqasid untuk Pemula (Suka Press, tk; tt), hlm 4

17 Idem, 4-5 
Hadirnya pernikahan Islam membawa angin segar terutama bagi kalangan perempuan, di mana Islam menganggap laki-laki dan perempuan sama, mempunyai hak dan kewajiban yang seimbang sebagai suami dan istri.

Pernikahan Islam lalu menjelaskan beberapa aturan yang berkaitan dengan hubungan suami Istri, seperti anjuran untuk menikah dan larangan membujang, aturan tentang poligami, aturan tentang talak, aturan tentang larangan berzina, aturan tentang kbulu', fasakh, dan aturan lainnya yang tidak pernah dikenal sebelumnya, atau kalaupun sudah ada aturan, dirasa belum memposisikan suami dan istri secara seimbang sehingga sering terjadi ketidakadilan dalam pola hubungan berkeluarga. ${ }^{18}$

2. Menjaga keturunan

Nabi Muhammad mengajurkan umat Islam untuk memilih calon pasangan yang subur (bisa melahirkan anak) karena termasuk dari tujuan pernikahan adalah menjaga keturunan, artinya melahirkan anak sebagai penerus perjuangan orang tuanya. Menjaga keturunan berarti menjadikan laki-laki sebagai seorang ayah dan seorang istri sebagai seorang ibu.

Tujuan menjaga keturunan ini menjadi sangat penting demi keberlanjutan kehidupan manusia. Tidak bisa dibayangkan jika semua umat Islam di dunia sepakat untuk tidak menikah dan tidak melahirkan keturunan, maka secara perlahan umat Islam akan semakin sedikit dan yang lebih bahaya lagi adalah umat Islam akan punah. Institusi pernikahan menjadi sangat urgen melihat tujuan pernikahan ini.

Oleh karena itu, ada beberapa aturan pernikahan yang tujuannya agar menjaga keturunan ini tetap terealisasi, di antaranya adalah keharusan menikah dengan lain jenis (laki-laki dan perempuan) dan larangan menikah dengan sesama jenis (laki-laki dan laki-laki, dan perempuan dengan perempuan), adanya larangan mengeluarkan sperma di luar kelamin istri dengan alasan agar tidak punya anak, larangan membujang, larangan melakukan tindakan medis terhadap

18 Jamaluddin 'Atiyyah, Nahwa Taf'il Maqasid Shri'ah (Damaskus: Dar al-fikr, 2001), 149 
alat reproduksi perempuan agar terhindar untuk mempunyai anak, dan aturan lainnya. ${ }^{19}$

3. Menciptakan keluarga yang sakinah, mawaddah, wa rahmah

Tujuan pernikahan tidak sekedar untuk menyalurkan kebutuhan biologis semata, akan tetapi juga erat kaitannya dengan menciptakan kondisi psikologis yang tenang, damai, dan tentram dengan balutan cinta kasing sayang antara suami dan istri. Pernikahan menjadi pintu gerbang bagi suami dan istri untuk saling mencurahkan kasih sayangnya satu sama lain sehingga perasaan tenang dan damai akan tercipta. Kalaupun ada konflik, itu tidak lebih dari sekedar bumbu cinta yang akan mewarnai sedapnya romantisme berkeluarga.

Agar tujuan ini terealisasi, Islam mengatur pola hubungan suami istri yang dideskripsikan dengan "mu'asharah bi al-ma'ruf", yaitu memperlakukan suami atau istri dengan cara-cara terbaik yang tidak akan menyakiti kedua pasangan, Islam juga mengatur tata krama berhubungan seksual, dan aturan lainnya. ${ }^{20}$

4. Menjaga garis keturunan

Menjaga garis keturunan berbeda dengan menajga keturunan. Menjaga keturunan berarti pernikahan diharapkan akan melahirkan seorang anak dan menjadikan suami sebagai ayah dan istri sebagai ibu. Sedangkan menjaga garis keturunan, tidak sekedar melahirkan seorang anak, tapi melahirkan seorang anak dari pernikahan yang sah sehingga jelas garis keturunannya dan siapa bapak ibu sahnya.

Untuk merealisasikan tujuan ini, Islam melarang keras perzinahan yang berakibat pada ketidakjelasan nasab sorang anak, Islam juga melarang mengadopsi anak dengan tujuan menjadikan anak angkatnya sebagai anak keturunannya sendiri, ada larangan menyembunyikan status anak dalam rahim, ada juga aturan tentang masa iddah, dan aturan lainnya. ${ }^{21}$

5. Menjaga keberagamaan dalam keluarga

Tujuan ini sangat jelas ketika membahas tentang kriteria calon pasangan yang ideal untuk dijadikan pendamping hidup selamanya

\footnotetext{
${ }^{19}$ Ibid, 150

20 Ibid.,

${ }^{21}$ Ibid,151
} 
(suami atau sitri). Nabi Muhammad saw. memberikan gambaran bahwa ada 4 kriteria yang harus jadi pertimbangan ketika memilih calon suami-istri, yaitu sisi fisik, sisi kelaurga, sisi ekonomi, dan sisi agama. Keempat kriteria tersebut diharapkan menjadi pertimbangan kuat ketika memilih calon suami atau istri. Akan tetapi, dari keempat kriteria tersebut, hanya agama dan keberagamaannyalah yang harus menjadi pertimbangan utama dibandingkan tiga kriteria lainnya. ${ }^{22}$

6. Mengatur pola hubungan yang baik dalam keluarga

Berkeluarga berarti memasuki jenjang baru dari kelas kehidupan yang dialami oleh manusia. Sebelum berkeluarga, tidak banyak hak dan kewajiban yang dialami dan masih terkesan bebas melakukan apapun yang dinginkan. Setelah masuk pada jenjang berkeluarga, maka suami dan istri, begitu juga anak yang dilahirkan akan dihadapkan pada beberapa aturan yang merangkai pola hubungan antara anggota keluarga. Suami dan sitri akan terikat pada hak dan kewajiban yang harus dipenuhi, begitu juga pola hubungan antara anak dan orang tua.

Berkeluarga juga berdampak pada lahirnya pola hubungan baru yang dilengkapi dengan aturan-aturan yang mengikat, seperti pola hubungan kekerabatan, pola hubungan mahram, pola hubungan kewalian, dan pola hubungan lainnya yang oleh Islam diatur sedemikian rupa sehingga tidak ada ruang bagi anggota keluarga untuk melakukan tidak semena-mena yang jauh dari rasa keadilan dan kemaslahatan. ${ }^{23}$

7. Mengatur aspek finansial keluarga

Pernikahan Islam menjadi pintu masuk lahirnya aturan-aturan baru yang berkaitan dengan aspek finansial, seperti adanya kewajiban suami memberi mahar kepada istri sebagai bukti bahwa dia adalah laki-laki yang serius dan bertanggung jawab, suami juga punya kewajiban memberi nafkah kepada istri dan juga anak-anaknya, termasuk juga memberi nafkah untuk istri yang dicerai, memberikan upah bagi ibu susuan, adanya hukum kewarisan, hukum wasiat

\footnotetext{
22 Ibid, 153

${ }^{23}$ Ibid, 154
} 
kepada kerabat, wakaf keluarga, perwalian harta, dan aturan lainnya yang berkaitan dengan aspek finansial. ${ }^{24}$

Maqasid shariah di atas menjadi gambaran yang sangat jelas bagimana menentukan batas usia yang ideal untuk menikah. Batas usia yang ideal adalah ketika pernikahan dilakukan pada usia tersebut, kemungkinan besar maqasid shari'ah dan tujuan-tujuan pemberlakuan hukum pernikahan Islam akan terealisasi. Sebaliknya, usia yang tidak ideal untuk menikah adalah ketika pernikahan dilangsungkan yang kemungkinan besar tujuan-tujuan pernikahan tidak akan tercapai, kalaupun tercapai tapi tidak akan sampai pada batas maksimal. Inilah prinsip batas usia menikah yang ideal.

Sebagaimana dijelaskan sebelumnya, ada tiga perspektif mengenai batas usia menikah, pertama, perspektif hukum Islam, kedua, undang-undang no 11974 tentang perkawinan, dan ketiga, program pendewasaan usia perkawinan $\mathrm{BKKBN}$.

Perlu menajdi catatan penting di sini, walaupun dalam al-Qur'an maupun al-Sunnah tidak pernah dijelaskan secara rinci tentang batasan umur, bahkan ulama' fiqh-pun masih berbeda pendapat terkait dengan batas umur baligh seseorang, ${ }^{25}$ akan tetapi bukan berarti hukum Islam tidak memberikan batas usia ideal untuk melangsungkan pernikahan. Usia ideal menikah dalam Islam bisa diungkap melalui teori maqasid shariah, sebagaimana dalam kajian sejarah hukum Islam, banyak peristiwa dan kejadian baru yang akhirnya menjadi sebuah hukum berlandaskan maqasid shariah. Pada zaman Khalifah Umar Bin Khattab, banyak aturan-aturan dan kebijakan-kebijakan baru yang tidak pernah dilakukan oleh Rasulullah saw. dan tidak ada penjelasan dari al-Qur'an. Dalam buku Metodologi Ijtihad Umar Bin Khattab disebutkan ada sebelas (11) kebijakan baru yang tidak ada penjelasan nash khususnya' diantaranya

24 Ibid.,

${ }^{25}$ Menurut jumbur ulama' membatasi umur balîg 15 bagi perempuan dan 18 bagi laki-laki. Sedangkan hanâfiyah berpendapat bahwa umur balìg adalah 17 tahun. 
adalah kebijakan dan aturan tentang Undang-Undang Administrasi dan Kepegawaian. ${ }^{26}$

Jika melihat tujuan dari maqasid shari'ah dalam pensyari'atan pernikahan, ketiga perspektif memiliki pandangannya masingmasing sesuai waktu dan tempat serta kebutuhannya. Jika melihat hukum Islam yang berlaku pada masa Nabi, persoalan usia menikah bukanlah persoalan yang urgen, karena Nabi adalah manusia yang ma'sum (terjaga dari dosa) sedangkan para sahabat sebagaimana dijelaskan Nabi, bagaikan bintang-bintang yang sekiranya kita mengikuti jejak langkahnya, maka kita akan mendapatkan petunjuk yang jelas. Oleh karena itu, berapapaun usia nikah bagi laki-laki dan perempuan, bukan menjadi persoalan penting untuk merealisasikan tujuan-tujuan shariah pemberlakuan hukum pernikahan Islam.

Sedangkan aturan yang berlaku dalam pasal 7 UU no 1 tahun 1974 tentang pernikahan, bahwa batas minimal usia menikah bagi perempuan adalah 16 tahun dan 19 tahun bagi laki-laki, hal ini juga berdasarkan kebutuhan masyarakat Indonesia dan sebagai jalan tengah dari batas usia yang terlalu rendah dan batas usia yang terlalu tinggi. Tapi pertanyaannya, apakah sebenarnya batasan usia nikah ini ideal untuk merealisasikan tujuan pensyariatan pernikahan? Walaupun secara hukum Islam dan hukum positif dinyatakan sah, akan tetapi belum dikatakan ideal karena dianggap belum mampu merealisasikan tujuan pensyariatan secara maksimal.

Sebagaimana dijelaskan tentang maqasid shariah tentang pernikahan, Jamaluddin 'Atiyyah menjealskan bahwa tujuan pernikahan diantaranya adalah menjaga keturunan, menciptakan

26 Ibid., 434. Khalifah Umar Bin Khattab membagi negara-negara yang dibebaskan Islam dalam wilayah-wilayah daerah teritorial tertentu, yang di dalamnya ada aturan-aturan yang berbentuk perundang-undangan keadministrasian dan data tentang pengadilan, data statistik, data akutansi. Termasuk aturan baru Khalifah Umar yang tidak ada nas khususnya adalah Undang-Undang tentang Administrasi Daerah dan Tata Kota. Khalifah juga mengangkat beberapa orang untuk mengatur administrasi daerah yang bekerja untuk mengatur proses dan sirkulasi keuangan daerah. Begitu juga Khalifah Umar mengangkat petugas yang disebut Asyir (petugas bea cukai), petugas penarik pajak, pegawai yang bekerja di Baitul Mal, dan petugas pemeriksa sirkulasi harta zakat. 
keluarga yang sakinah mawaddah wa rahmah, menjaga garis keturunan, menjaga pola hubungan keluarga, menjaga keberagamaan dalam keluarga, dan mepersiapkan aspek ekonomi. Beberapa tujuan ini tentunya tidak bisa direalisasikan secara maksimal karena umur 16 bagi perempuan bukanlah umur ideal, terutama berkaitan dengan kesehatan reproduksi.

Menurut dr. Ali Sibra M, Ketentuan usia perkawinan dalam pasal 7 ayat 1\&2 UU No.1 Tahun 1974 tidaklah cocok untuk dijadikan tolak ukur terjadinya sebuah perkawinan, karena pada usia di bawah 20 tahun seseorang masih belum mengalami kedewasaan dalam dirinya dan organ reproduksi belum matang dan tidak siap untuk mengalami kehamilan sampai persalinan. ${ }^{27}$

Secara sosial mereka akan mengalami kesulitan dalam menjalani bahtera rumah tangga dan hidup bermasyarakat dengan masyarakat sekitar. Perkawinan dalam usia di bawah 20 tahun akan mengakibatkan putusnya sekolah dan membuat wanita secara permanen menjadi tidak mandiri dan selalu bergantung pada suaminya, sehingga nantinya akan mempengaruhi pada status sosial dan ekonomi. Seorang istri yang masih remaja biasanya mempunyai pendidikan yang rendah sehingga mereka mengalami ketergantungan kepada suami dan keluarganya, termasuk juga dalam hal pelayanan kesehatan reproduksi. Dengan demikian mereka lebih mungkin terjadi banyak risiko kesehatan, kekerasan, infeksi menular seksual termasuk HIV dan AIDS. ${ }^{28}$

Mengenai bahaya medis yang dapat terjadi ketika seorang menikah pada usia di bawah 20 tahun, ada 5 bahaya yang timbul darinya, yakni:

1) Berat Bayi Labir Rendah (BBLR) bahwasanya remaja perempuan yang hamil berisiko lebih tinggi untuk melahirkan bayi dengan berat badan yang rendah. Hal tersebut karena bayi memiliki waktu yang kurang dalam rahim untuk tumbuh. Bayi lahir

27 Tsamrotun kholilah, Analisis Hukum Islam terhadap Pandangan Abli Medis Tentang Usia Perkawinan Menurut Pasal 7 ayat $1 \ll 2$ UU No.1 tabun 1974 (Skripsi, tidak diterbitkan), 60

$28 \mathrm{ibid}$ 
dengan berat badan rendah biasanya memiliki berat badan sekitar 1.500-2.500 gram dan Ibu yang hamil pada usia muda biasanya pengetahuannya akan gizi masih kurang, sehingga akan berakibat kekurangan berbagai zat yang diperlukan saat pertumbuhan dengan demikian akan mengakibatkan makin tingginya kelahiran prematur, berat badan lahir rendah dan cacat bawaan.

2) Pre-eklampsia dan Eklampsia (keracunan kehamilan) yakni Kombinasi keadaan alat reproduksi yang belum siap hamil dan anemia makin meningkatkan terjadinya keracunan hamil dalam bentuk pre-eklampsia atau eklampsia. Pre-eklampsia dan eklampsia memerlukan perhatian serius karena dapat menyebabkan kematian.

3) Abortus atau Keguguran, pada saat hamil seorang ibu muda, sangat memungkinkan terjadi keguguran. Hal ini disebabkan oleh faktor-faktor alamiah dan juga abortus yang disengaja, baik dengan obat-obatan maupun memakai alat.

4) Kesulitan Persalinan adalah Persalinan yang disertai komplikasi ibu maupun janin. Penyebab dari persalinan lama sendiri dipengaruhi oleh kelainan letak janin, kelainan panggul, kelainan kekuatan his, mengejan serta pimpinan persalinan yang salah. Kematian ibu dan karena perempuan yang berusia di bawah 20 tahun, mereka biasanya tidak tahan dengan rasa sakit sehingga dilakukannya oprasi lebih besar daripada melahirkan secara normal.

5) Meningkatkan Resiko Kanker Serviks atau Kanker Leher Rahim (KLR) karena semakin muda usia pertama kali seseorang berhubungan seks, maka semakin besar risiko daerah reproduksi terkontaminasi virus. ${ }^{29}$

Kemudian, dr. Ali Sibran $M$ berpendapat tentang usia perkawinan yang ideal menurut ilmu kesehatan yakni ketika seorang perempuan berusia 20 tahun dan seorang laki-laki berusia 25 tahun, dimana ketika usia 20 tahun dan 25 tahun secara fisik mereka sudah

${ }^{29}$ Ibid, 61-62 
matang dan alat reproduksi perempuan sudah matang sehingga ketika terjadi pembuahan dan kehamilan akan mengurangi bahaya yang telah diuraikan di atas. ${ }^{30}$

Sedangkan menurut dr. Akhmad Khof Albar, SpOG, ketentuan batas usia menikah untuk seorang perempuan 16 tahun dan 19 tahun untuk laki-laki dalam pasal 7 ayat 1\&2 tahun 1974 menurutnya tidaklah sesuai dengan keadaan kesehatan reproduksi pada seorang wanita dimana dalam usia 20 tahun ke bawah seorang wanita masih mengalami proses pematangan alat reproduksi sehingga dalam usia 20 tahun jika ia mengalami kehamilan akan terjadi perebutan gizi antara ibu dan anak. Bahaya yang akan terjadi dalam masa kehamilan di bawah usia 20 tahun yang pasti akan terjadi, diantaranya: Angka Kematian Ibu (AKI) dan Angka Kematian Anak (AKA) akan meningkat lebih tinggi, karena resiko kehamilan dan persalinan perempuan yang berusia di bawah 20 tahun lebih besar daripada kehamilan dan persalinan pada usia 20 tahun ke atas. ${ }^{31}$

Lebih lanjut dr. Akhmad Khof Albar, SpOG menjelaskan bahwa ketentuan batas usia perkawinan dalam pasal 7 ayat $1 \& 2$ UU N0.1 Tahun 1974 akan mengakibatkan kerugian-kerugian yang didapat oleh pihak wanita dan harus adanya revisi pasal di atas karena jarak pembuatan UU dengan sekarang pun sangat jauh. Sehingga sudah layaknya pasal di atas direvisi dengan pertimbangan-pertimbangan di atas, karena kondisi pada tahun 1974 sangatlah berbeda dengan tahun 2015 dimana pergaulan yang dialami tahun 1974 dan sekarang sangat berpengaruh dalam psikologi anak.

Menurut dr. Akhmad Khol Albar, SpOG, umur yang ideal untuk melakukan perkawinan sesuai dengan kesehatan reproduksi, kesiapan mental dan keselamatan Ibu dan Bayi adalah ketika seorang wanita berusia di atas 20 tahun. Jadi ketika seorang wanita mengalami kehamilan dan persalinan ketika usia di atas 20 tahun maka bahayabahaya yang tertuang di atas tidak akan terjadi dan tujuan dari

\footnotetext{
${ }^{30}$ Ibid, 63

31 Ibid, 57-58
} 
perkawinan itu sendiri akan tercapai yakni menjadi keluarga yang sakinah, mawaddah dan rabmah.. ${ }^{32}$

Dalam sebuah penelitian yang dilakukan oleh LKBH Fakultas Hukum Universitas Wiralodra, Indramayu, menyimpulkan bahwa banyak sekali perkawinan di bawah umur di Kecamatan Gabus Wetan Kabupaten Indramayu yang berakhir dengan perceraian. Bahkan setelah perceraian terjadi, sang perempuan pada umumnya lantas menjadi Tenaga Kerja Wanita (TKW) atau Pekerja Seks komersial (PSK). Parahnya, sang penjual itu adalah orang tuanya sendiri.

Melihat pandangan pakar medis dan hasil penelitian oleh LKBH di atas seakan membukaan mata kita bahwa sebenarnya menikah di usia di bawah 20 tahun justru akan mengakibatkan beberapa bahaya bagi pasangan suami istri dan anak yang dilahirkan, yang justru jauh dari tujuan-tujuan yang diharapkan dari pensyari'atan pernikahan. Oleh karena itu, pernikahan di bawah usia 20 tahun bagi perempuan sebenarnya tidak mencerminkan dan tidak merealisasikan maqasid shari'ah pernikahan, oleh karena itu tidak bisa dikateogrikan sebagai usia perkawinan yang ideal.

Usia perkawinan yang ideal adalah perkawinan yang dilangsungkan oleh laki-laki yang berumur minimal 25 tahun dan perempuan minimal 20 tahun. Batas usia minimal ini menjadi usia ideal perkawinan karena mampu merealisasikan tujuan-tujuan pernikahan sebagaimana yang dijelaskan oleh Jamaluddin Atiyyah, yaitu menjaga keturunan, menciptakan keluarga yang sakinah mawaddah wa rahmah, menjaga garis keturunan, menjaga pola hubungan keluarga, menjaga keberagamaan dalam keluarga, dan mepersiapkan aspek ekonomi. Batas usia ideal tersebut dianggap telah siap dan matang dari aspek medis, psikologis, sosial, dan tentunya agama sehingga bisa menciptakan keluarga sesuai dengan maqasid shari'ah pensyariatan pernikahan.

Batas usia ideal perspektif maqasid shari'ah ini juga sesuai dengan harapan pemerintah (BKKBN) melalui program pendewasaan usia perkawinan. Program KB mengembangkan program Pendewasaan

32 Ibid, 59 
Usia Perkawinan (PUP) yang menganjurkan usia kawin yang ideal untuk menikah dan memiliki anak pertama, yaitu usia minimal 20 tahun bagi perempuan dan 25 tahun bagi laki. Batasan usia ini dianggap sudah siap baik dipandang dari sisi kesehatan maupun perkembangan emosional untuk menghadapi kehidupan berkeluarga. ${ }^{33}$.

\section{Penutup}

Ada dua kesimpulan penting sebagai penutup dari tulisan ini, Pertama. batas usia ideal pernikahan tidak pernah disinggung secara jelas oleh teks al-Qur'an dan as-Sunnah. Secara umum keduanya hanya mendeskripsikan bahwa kedua calon mempelai yang akan menikah harus mencapai umur yang patut untuk melangsungkan pernikahan. Adanya ketidakjelasan inilah yang juga menyebabkan sikap ulama' fiqh khususnya empat mazhab yang tidak menjelaskan secara tegas dan masih ada perbedaan pendapat tentang batas umur pernikahan. Secara umum ulama' fiqh hanya menjelaskan bahwa calon suami istri haruslah dewasa.

Kedua, Walaupun dalam al-Qur'an dan as-Sunnab tidak ada penjelasan secara rinci tentang batasan usia menikah. akan tetapi usia ideal perkawinan perspektif maqasid shari'ab adalah 25 tahun bagi lakilaki dan 20 tahun bagi perempuan. Batas usia minimal ini menjadi usia ideal perkawinan karena mampu merealisasikan tujuan-tujuan pernikahan seperti menjaga keturunan, menciptakan keluarga yang sakinah mawaddah wa rahmah, menjaga garis keturunan, menjaga pola hubungan keluarga, menjaga keberagamaan dalam keluarga, dan mepersiapkan aspek ekonomi. Juga dianggap telah siap dan matang dari aspek medis, psikologis, sosial, dan tentunya agama. sehingga bisa menciptakan keluarga sesuai dengan maqasid shari'ab pensyariatan pernikahan.

${ }^{33} \mathrm{BKKBN}$; Direktorat Remaja dan Perlindungan Hak-Hak Reproduksi, Pendewasaan Usia Perkawinan dan Hak-hak Reproduksi bagi Remaja Indonesia Perempuan, (Jakarta: 2010), 19 


\section{Daftar Pustaka}

Abdurrahman al-Jaziriy. Kitab al- Figh Ala Madzahib al- Arba'ah, Jilid 4. Beirut: Darul Fikr, t.t

Ahmad al-Raisuni. al-Fikru al-Maqasidi Qawa'idubu wa Fawaidubu.Dar al-Baida': Ribat: 1999

Amir Syarifuddin. Hukum Perkaninan Islam di Indonesia. Jakarta, Kencana, 2006

BKKBN; Direktorat Remaja dan Perlindungan Hak-Hak Reproduksi, Pendewasaan Usia Perkawinan dan Hak-hak Reproduksi bagi Remaja Indonesia Perempuan. Jakarta: 2010

Departemen Agama RI. al-Qur'an dan Terjemahannya. Surabaya, Surya Cipta Aksara, 1993

Husein Muhammad. Fiqh Perempuan. Yogyakarta: LKIS. 2007

Jamaluddin 'Atiyyah. Nahwa Taf'il Maqasid Shri'ah. Damaskus: Dar alfikr, 2001

Jasser Auda. Maqasid al-Shari'ah as Philosophy of Islamic Law: A System Approach. London \& Washington: The International Institute of Islamic Thought, 2008

-------. Maqâsid al-Sharîah: A Beginner's Guide, terjemah oleh 'Ali Abdelmon'im, Al-Maqâsid untuk Pemula. Suka Press, tk; tt

Jumansyah. Analisis Penerapan Good Governance Business Syariah dan Pencapaian Maqashid Shariah Bank Syariah di Indonesia, dalam Jurnal Al-Azhar Indonesia Seri Pranata Sosial, Vol. 2, No. 1, Maret 2013.

Matthe B. Miles, A. Michael Huberman. 1992. Qualitative Data Analysis, Tjetjep Rohendi Rohidi (Penerjemah) Analisa Data Kualitatif, Buku Sumber Tentang Metode-Metode Baru. Jakarta, $\mathrm{UI}=$ Press. 
Moh. Hefni. Rekonstruksi Maqâshid al-Syarîah (sebuah gagasan hasan hanafi tentang revitalisasi turâts, dalam Jurnal al-Ihkam, vol. 6 no. 2 desember 2011.

Siti Zumrotun. Al-Maqasid: Alternatif Pendekatan Ijtihad Zaman Kontemporer dalam "Ijtihad Jurnal Wacana Hukum Islam dan Kemanusiaan, Volume 13, No. 1, Juni 2013.

Tsamrotun Kholilah. Analisis Hukum Islam terhadap Pandangan Ahli Medis Tentang Usia Perkawinan Menurut Pasal 7 ayat 1 \& 2 UU No.1 tahun 1974. Skripsi, tidak diterbitkan

Wahbah Zuhailiy. Al-Fiqh al-Islâmi wa Adillatuhu, juz 9. tk: tp, tt www.bkkbn.go.id/arsip/.../RENSTRA\%20BKKBN\%2020102014.pdf (diakses 12 Januari 2014)

Yubsir. Maqâshid Shariah Sebagai Metode Interpretasi Teks Hukum: Telaah Filsafat Hukum Islam, dalam Jurnal al-Adalah Vol. xi No. 2 juli 2013. 
Batas Usia Ideal Pernikahan 